\title{
A hundred years of the Polish Geological Institute Editorial
}

This special issue of Geological Quarterly is dedicated to the celebration of the 100th anniversary of the establishment of the Polish Geological Institute - National Research Institute in 1919. The mission of the Institute was not only to fulfil all the tasks of the state geological survey, but also to develop national geological science. Geological Quarterly is the leading journal of the Institute, with a wide international auditorium. It is an excellent forum to present a selection of the most recent scientific achievements of the PGI-NRI in regional geology of Poland, supported with novel approaches in the adjacent countries and backed up by modern data and methodology. This Anniversary Volume expresses therefore a thorough overview, far from being complete, of the current state of geology in a broader regional context crossing national borders.

Ryszard Habryn et al. re-analysed detrital zircon age of conglomerates from the Upper Silesia (USB) and Małopolska (MB) blocks (S Poland) to compare their possible provenances. The size and poor sorting of lithoclasts reflect a short transportation, with deposition close to the source land. Detrital zircon clusters dated at 579-585 Ma, 628-638 Ma and $707 \mathrm{Ma}$ are consistent with the distribution of Cadomian magmatism within the nearest orogenic belt or those identified elsewhere within the Brunovistulicum.

The paper by Teresa Podhalańska et al. presents the latest data on the vertical and lateral ranges and characteristics of prospective zones within the Lower Paleozoic unconventional hydrocarbon system of the East European Craton in Poland. The zones, distinguished within the Lower Paleozoic shale formations of the Baltic-Podlasie-Lublin Basin, are described based on strictly determined criteria with application of stratigraphic, sedimentological, mineralogical, petrographic, geochemical, petrophysical and geomechanical studies, and interpretations of borehole logs.

The paper by Marek Narkiewicz presents a reconsideration of the earlier concept of the Variscan foreland in Poland in the light of new stratigraphic, tectonic and geophysical evidence, providing new data on Devonian sedimentation, Carboniferous magmatism and the deep crustal structure of SE Poland. Regional comparisons with the tectonic evolution of Central Europe and the Black Sea region show that the subsidence pattern in the foreland was controlled by alternating phases of accelerated convergence and tectonic standstill along the southern margin of Euramerica.

The paper prepared by Janina Wiszniewska et al. contains a review of all available geological data on the Tajno Massif, which intruded the Paleoproterozoic crystalline basement of NE Poland (Mazowsze Domain) north of the TeisseyreTornquist zone, on the East European craton. The massif (to- gether with the nearby Ełk and Pisz intrusions) occurs beneath a thick Mesozoic-Cenozoic sedimentary cover. It was first recognized by geophysical (magnetic and gravity) investigations, then by drilling (12 boreholes to a depth of $1800 \mathrm{~m}$ ). Recent geochronological data (U-Pb on zircon from albitite, and Re-Os on pyrrhotite from carbonatite) indicate that the massif was emplaced at $348 \mathrm{Ma}$ (Early Carboniferous).

Aleksandra Kozłowska and Maria I. Waksmundzka estimated reservoir properties of Carboniferous deposits in the southeastern part of the Lublin Basin, based on diagenetic and sequence stratigraphic patterns.

Anna Becker et al. present new chronostratigraphic results of Lower Triassic deposits of the epicontinental Central European Basin, based on microspore biostratigraphy and magnetostratigraphy in drill cores from the Bartoszyce IG 1 , Nidzica IG 1 and Pasłęk IG 1 boreholes.

Karol Zglinicki and Krzysztof Szamałek discuss ophiolitic rocks of the Cyclops Mountains Massif as the source for metal-bearing shelf sediments of the Carolinian Sea. These sediments are enriched in heavy minerals containing elevated concentrations of Ni, W and Co, as well as V, An and REE.

Tetyana Solovey successfully applied high-resolution multispectral images provided by the Sentinel 2 satellite to predict areas at risk of flooding, based on a case study from the Kampinos National Park. The important advantage of the analytical procedure used in the study is that such technologies, obtained thanks to the activities of The European Space Agency, are available free of charge in the public domain, and therefore can be used on a large scale.

Maciej R. Kłonowski et al. focused on the evaluation and statistical interpretation of low-temperature geothermal energy potential for selected locations in Poland. It fulfils requirements of national, EU and other international regulations on climate and energy, which imply significant growth of renewables' share in the total mix of energy production in Poland.

The papers presented in this $100^{\text {th }}$ Anniversary Volume of Geological Quarterly are excellent examples of the recent progress in understanding regional geology of Poland. They are the evidence that the input of the PGI-NRI as the Polish Geological Survey is irreplaceable in creating new models of the geological structure of Poland, based on application of the most modern techniques and methods, and in agreement with highest international standards. It also shows that PGI employees conduct methodological work and, taking care of the security of raw materials of the state, carry out work outside the country.

Leszek Marks and Stanisław Wołkowicz 